\title{
Author Correction: Proteomic and interactomic insights into the molecular basis of cell functional diversity
}

\section{Isabell Bludau (D) and Ruedi Aebersold (D)}

Nature Reviews Molecular Cell Biology (2020) https://doi.org/10.1038/s41580-020-0231-2 Published online 31 March 2020

The portrayal of processed mRNAs in FIG. 1 included introns. This has now been corrected. Following this correction, the protein elements in the figure have been changed to oval shapes to make the depiction of RNA and proteins more distinct. The changes have been made in the html and PDF versions of the article.

https://doi.org/10.1038/s41580-020-0249-5 I Published online 17 April 2020

(c) Springer Nature Limited 2020

है

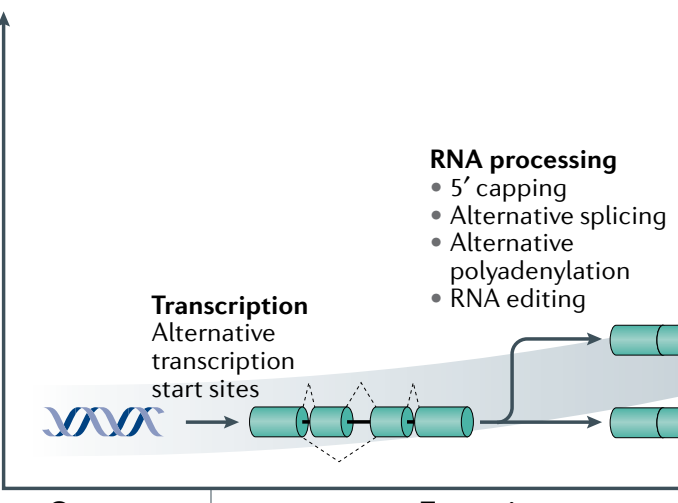

Genome

Transcriptome

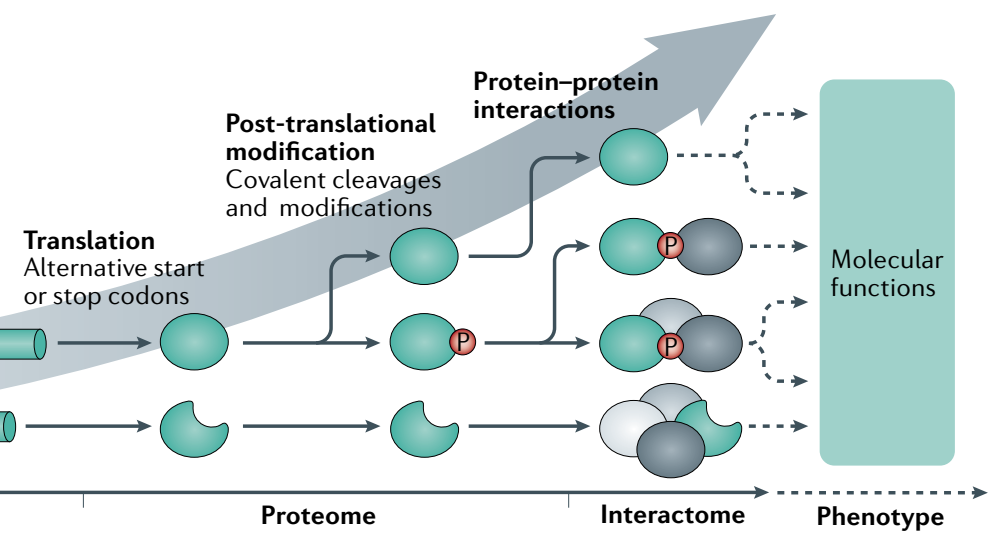

Fig. 1 | Corrected. 